$\overline{\text { 論文 }}$

\title{
森林の多面的機能を題材とした森林教育テキストの作成方針 一既存の森林教育テキストの比較解析から一
}

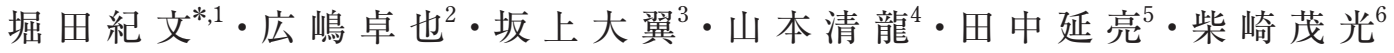

\begin{abstract}
堀田紀文・広嶋卓也・坂上大翼・山本清龍・田中延亮・柴崎茂光：森林の多面的機能を題材とした森林教育テキストの作 成方針一既存の森林教育テキストの比較解析から一 日林誌 $89: 374 \sim 382,2007$ 森林の多面的機能を題材とする森林 教育を実施する際に，指導者となる学校教員を対象としたテキストを活用することが有効であるとの立場から，既存の森林 教育テキストの内容をレビューし，プログラムにおける多面的機能の取り上げ状況とテキストの構造に着目した整理を行っ た。結果として, 森林の機能を題材とした森林教育プログラムはすでに多数存在することが示された。また, 森林教育テキ ストは，プログラムとそれに対応するテーマ（主題・背景）によっていくつかの構造に類型化できた。今後，森林の多面的 機能を題材としたテキストを作成する際には, 既存のプログラムを参照することが可能であり，テキストには，プログラム とそれに対応した森林の多面的機能に関するテーマの組み合わせを複数盛り込むことで, インタープリテーションを通して 森林の多面的機能に対する理解を促進できると考えられた。

キーワード：森林教育, 森林教育テキスト, 森林教育プログラム, インタープリテーション, 森林の多面的機能
\end{abstract}

Hotta, N., Hiroshima, T., Sakaue, D., Yamamoto, K., Tanaka, N., and Shibasaki, S. : An Editorial Policy for Forest Education Textbooks to Promote Better Understandings of the Multiple Functions of Forest: A Comparison of Forest Education Textbooks. J. Jpn. For. Soc. 89: 374 382, 2007 Instructional textbooks can help educators to promote better forest education programs. We analyzed and compared ten forest education textbooks to find a policy of developing texts to facilitate better understandings of the multiple functions of forest by examining how the textbook contents addressed these multiple functions. We found that about half of all programs have already been developed to encompass the multiple functions of forest, and are suitable for use in forest-education programs. The ten textbooks were classified into four contextual groups, according to the relationship between a particular topic related to an education program and its interpretation in the textbook, as follows. Group a: textbooks that contained no interpretation; group b: textbooks that contained several interpretations, and each interpretation corresponded to a particular program; group c: textbooks that contained several interpretations and each interpretation bound several programs; and group d: textbooks in which all programs were accounted for under one interpretation. Textbooks with several interpretations (groups b and c) contained more programs that were welllinked to forest functions than the other textbooks. To promote the multiple functions of forest in forest education, textbooks should contain separate interpretations that address forest functions, and clear links should be established between each program and its interpretation.

Key words: forest education, forest education program, forest education textbook, interpretation, multiple forest functions

\section{I. はじめに}

近年, 子供達をはじめ広く国民を対象とした森林教育が 大きな関心を集めている。小中学校教育の現場では, 2002
年以降，「総合的な学習の時間」が本格導入されたことを契 機として環境教育がさまざまな形で取り入れられるように なった。また， 2003 年には「環境の保全のための意欲の増 進及び環境教育の推進に関する法律」が施行された。こう

* 連絡・別刷請求先 (Corresponding author) E-mail: hotta@fr.a.u-tokyo.ac.jp

1 東京大学大学院農学生命科学研究科森林科学専攻 (113-8657 東京都文京区弥生 1-1-1)

Department of Forest Sciences, Graduate School of Agricultural and Life Sciences, The University of Tokyo, 1-1-1 Yayoi, Bunkyo-ku, Tokyo 113-8657, Japan.

2 東京大学大学院農学生命科学研究科附属科学の森教育研究センター千葉演習林（299-5503 鴨川市天津 770）

University Forest in Chiba, The University Forests, Graduate School of Agricultural and Life Sciences, The University of Tokyo, 770 Amatsu, Kamogawa 299-5503, Japan.

3 東京大学大学院農学生命科学研究科附属科学の森教育研究センター田無試験地（188-0002 西東京市緑町 1-1-8）

Experimental Station at Tanashi, The University Forests, Graduate School of Agricultural and Life Sciences, The University of Tokyo, 1-1-8 Midori-cho, Nishi-Tokyo, Tokyo 188-0002, Japan.

4 東京大学大学院農学生命科学研究科附属科学の森教育研究センター富士演習林 (401-0501 山梨県南都留郡山中湖村山中 341-2)

University Forest at Yamanakako, Graduate School of Agricultural and Life Sciences, The University of Tokyo, 341-2 Yamanaka, Yamanakakomura, Minamitsuru-gun, Yamanashi 401-0501, Japan.

5 東京大学大学院農学生命科学研究科附属科学の森教育研究センター愛知演習林 (489-0031 瀬戸市五位塚町 11-44) University Forest in Aichi, Graduate School of Agricultural and Life Sciences, The University of Tokyo, 11-44 Goizuka, Seto 489-0031, Japan.

6 岩手大学農学部地域マネジメント学講座（020-8550 盛岡市上田 3-18-8）

Regional Resource Management, Department of Environmental Sciences, Faculty of Agriculture, Iwate University, 3-18-8 Ueda, Morioka 0208550, Japan.

（2006 年 10 月 11 日受付；2007 年 6 月 15 日受理) 
した流れを受けて森林教育研究の分野でも，ここ数年，小 中学校における森林教育の実践例が多数報告されるように なった。

これらの事例における森林教育の際の指導者は, 森林ボ ランティア団体 (奥山ら，2003)，森林経営者・森林組合な どの林業従事者（楢崎ら，2004），大学教員・研究者（井 倉，2003；松尾ら，2004；大石ら，2003）など，校外から 派遣された専門家である例が大半で, 佐藤・青柳（2003） が指摘するように，学校教員自らが森林教育を行うことは まれなようである。しかしながら，校外の専門家が直接指 導できる人数には時間や予算の面で制約があり，また，専 門家との接点をもつ学校は限られるため, 森林教育を広く 普及させるためには学校教員自らが指導者になることが重 要と考えられる。一方, 森林教育が実施されるフィールド は, 大学演習林（芦原ら, 2003 ; 井倉, 2003 ; 井倉ら, 2004）を活用する事例が一部みられるものの，学校林を活 用した事例報告（上沼，2003；奥山・茂田， 2003 ; 大石， 2001 ; 島田, 2003) が多い。したがって, 学校教員自らが 指導者になることによって, 身近なフィールドでの教育プ ログラムの実施が可能となり, 森林教育が普及することが 期待される。

学校教員自らが指導者となって森林教育を実施していく にあたり，専門家による支援が望まれる（広嶋ら，2006）。 ここで, 比屋根（2001）が指摘しているょうに，専門家は 学校における森林教育に対して一定の責任を負うべきであ り，学校教員との連携のもと，教育目標の設定，教育の実 践, 教育効果の分析, 分析結果のフィードバックによる教 育内容の改善という一連の手順を完遂することが重要であ る（比屋根, 2001; 大石, 2001 ; 比屋根ら, 2002)。このよ うな観点から, 山梨県の教育研究者・森林行政担当者らが, 県内の小中学校の教員を対象に指導者養成のための研修を 実施した例（島田，2003）や，大学教員のグループが富士 山周辺の小中学校の教員を対象として, 森林の多面的機能 を題材とした森林教育プログラムの研修を実施した例（広 嶋ら，2006）が報告されており，これらの研修では独自の 森林教育マニュアルやテキストが教材として使用されてい る。このように，森林教育テキストを作成することは，専 門家による支援として重要と考えられる。一方で, 森林教 育実施のための小中学校の教員向けテキストはすでにいく つか出版（たとえば，全国森林組合連合会，1999；北海道 林業改良普及協会, 2000）されていることから，専門家が 学校における森林教育に関与するにあたり, 既存のテキス トを活用することができる状況にあるといえよう。

広嶋ら (2006)が多面的機能を題材として森林教育を行っ ているように, 今後, 多面的機能を題材とした教育を通し て森林の理解を促すことは重要である。たとえば，森林の 水源涵養機能や炭素固定機能を考慮した環境税導入に関し て，住民がその是非を判断するような場合に森林の多面的 機能が理解されている必要があるなど，社会的な要請も大 きくなることが予想される。したがって，適切な教育プロ
グラムに基づいて多面的機能を題材とした森林教育が害施 されることは，森林やそれをとりまく社会にとって将来的 に大きな意義をもつと考えられる。また，学校教育におい ても, 専門家との連携のもとに多面的機能を扱った森林教 育プログラムを提供できることは, 総合的な学習の時間な どにおける学習内容の充実と研究成果の社会還元の両者に 結びつくことが期待できるため, 学校教育と専門研究の双 方にとって利点がある。このような状況を考えたとき，既 存の森林教育プログラムが森林の多面的機能の学習にどの 程度対応しているかを明らかにすることは, 既存のテキス 卜を参照して森林教育を実施する上でも，今後新たにテキ ストを作成していく上でも有用だといえるだろう。

以上のような観点から, 本研究では, 森林の多面的機能 を題材とした森林教育を実施するにあたって, 既存の森林 教育プログラムにおける多面的機能の取り上げられ方を明 らかにすることを目的として，いくつかの森林教育テキス トの内容について比較・整理と解析を行った。また，その 結果を踏まえて, 今後どのようなテキストを作成していく べきかを考察した。

\section{II. 対象とした森林教育テキストと解析方法}

\section{1. 解析対象とした森林教育テキスト}

森林教育のためのテキストはすでにいくつか公表されて いるが，その内容は専門的な解説書としての性格を帯びる ものから, 教育活動の現場を想定した実践的なものまで多 岐にわたる。本研究では, 教育現場への適用が比較的容易 であるとの観点から, 教育プログラムの具体的な実施手順 の記述がみられ, インターネット経由を含めて 2007 年 3 月 現在で入手可能なテキストを解析の対象として選定した (表-1)。結果として, 学校教育の中での森林教育を想定し たテキストが多く集められた。森林教育のみを題材として 作成されたものが大半であるが, 水田など森林以外の フィールドで実施するプログラムを含んだテキストも一部 存在する。また, アメリカ森林協議会（1999）のテキスト のように, 海外で開発された定評ある環境教育の教材（荻 原, 2002）のうち, 樹木や森林を取り扱ったものも選定し た。選定したテキストの中には, ホームページ上からの入 手を前提として, 出版されていないものもあった。これは, 選定したテキストの多くが県などの自治体によって作成さ れ，実際の教育現場での利用を想定して県内でのみ配布さ れるようなケースがあるためである。また,テキストによっ ては一部に森林を題材としないプログラムを含んでいた が, 森林を題材としないプログラムは解析対象から除外し た。

\section{2. 解析方法}

まず，テキストの構成やプログラム以外の記載項目に着 目して各テキストの内容について整理した上で, 解析対象 としたプログラムの絞り込みを行った（III.1.で詳述）。次 に，テキストに記載された個々の教育プログラムの内容に ついて, 以下に詳述する森林の多面的機能の取り上げとい 
表-1. 解析対象とした森林教育テキスト

\begin{tabular}{|c|c|c|c|c|}
\hline 番号 & タイトル & 作成者 & 入手先* & $\begin{array}{l}\text { プログラムの } \\
\text { 対象年齢 }\end{array}$ \\
\hline 1 & $\begin{array}{l}\text { 森で学ぶ＼cjkstart森林教育プログラム作成手 } \\
\text { 引き }\end{array}$ & 北海道林業改良普及協会（2000） & 出版：北海道林業改良普及協会, 札幌 & 小学生（1～6 年） \\
\hline 2 & $\begin{array}{l}\text { みやぎ環境学習プログラム 小学校中 } \\
\text { 学年 }\end{array}$ & $\begin{array}{l}\text { 宮城県環境生活部, } \\
\text { (財)みやき·環境とくらし・ネッ } \\
\text { トワーク }(2004)\end{array}$ & $\begin{array}{l}\text { 宮城県環境生活部環境政策課（http://www.pref. } \\
\text { miyagi.jp/kankyo-s/kankyokyoiku/education_ } \\
\text { program.htm） }\end{array}$ & 小学校 $3 \sim 4$ 年 \\
\hline 3 & $\begin{array}{l}\text { みやぎ環境学習プログラム 小学校高 } \\
\text { 学年 }\end{array}$ & $\begin{array}{l}\text { 宮城県環境生活部, } \\
\text { (財)みやき·環境とくらし・ネッ } \\
\text { トワーク (2004) }\end{array}$ & $\begin{array}{l}\text { 宮城県環境生活部環境政策課（http://www.pref. } \\
\text { miyagi.jp/kankyo-s/kankyokyoiku/education_- } \\
\text { program.htm） }\end{array}$ & 小学校 $5 \sim 6$ 年 \\
\hline 4 & $\begin{array}{l}\text { 森へ行こう 親しむ・知る・育てる } \\
\text { かながわの森 〜小中学生にさせた } \\
\text { い森林活動プログラム集〜 }\end{array}$ & $\begin{array}{l}\text { (社)かながわ森林づくり公社 } \\
\text { (2004) }\end{array}$ & $\begin{array}{l}\text { （社）かながわ森林づくり公社（http://www.ny. } \\
\text { airnet.ne.jp/k_sinrin/pro.htm） }\end{array}$ & $\begin{array}{l}\text { 小学生 }(1 \sim 6 \text { 年 }), \\
\text { 中学生 }\end{array}$ \\
\hline 5 & $\begin{array}{c}\text { 天竜美林の教え 〜天竜流域で行う森 } \\
\text { 林を中心とした環境学習の手引き〜 }\end{array}$ & $\begin{array}{l}\text { 静岡県中遠, 北遠, 西部農林事 } \\
\text { 務所 }(2004)\end{array}$ & $\begin{array}{l}\text { 静岡県環境森林部地球環境室（http://www.pref. } \\
\text { shizuoka.jp/kankyou/ka-030/kyoikudownload.html） }\end{array}$ & 小・中学生 \\
\hline 6 & $\begin{array}{l}\text { 駿東・田方地方で考える } \\
\text { 森林環境教育プログラム集 }\end{array}$ & $\begin{array}{l}\text { 静岡県環境森林部, 静岡県東部 } \\
\text { 農林事務所 (2004) }\end{array}$ & $\begin{array}{l}\text { 静岡県環境森林部地球環境室（http://www.pref. } \\
\text { shizuoka.jp/kankyou/ka-030/kyoikudownload.html） }\end{array}$ & 小・中学生 \\
\hline 7 & こども環境学習プログラム 山・里編 & 山口県環境政策課（2003） & $\begin{array}{l}\text { 山口県環境政策課（http://eco.pref.yamaguchi. } \\
\text { jp/study/network/kkgp.htm） }\end{array}$ & $\begin{array}{l}\text { 保育園・幼稚園 小 } \\
\text { 学低学年 }\end{array}$ \\
\hline 8 & $\begin{array}{l}\text { ふれあい・まなび・つくる〜森林環境 } \\
\text { プログラム 事例集〜 }\end{array}$ & 全国森林組合連合会（1999） & 出版：全国森林組合連合会，東京. & 子供〜扮年寄り \\
\hline 9 & $\begin{array}{l}\text { したしみ・きづき・まなぶ 森林環境 } \\
\text { 教育プログラム 事例集(2)一地方自 } \\
\text { 治体編一 }\end{array}$ & 全国森林組合連合会（2002） & 出版: 全国森林組合連合会, 東京. & 子供〜お年寄り \\
\hline 10 & $\begin{array}{c}\text { 木と学ぼう プロジェクト ラーニング } \\
\text { ツリー 活動事例集 (幼〜 小 } 6 \text { ) }\end{array}$ & $\begin{array}{l}\text { アメリカ森林協議会, } \\
\text { ERIC 国際理解教育センター編 } \\
\text { 訳 (1999) }\end{array}$ & 出版：国際理解教育センター, 東京. & 幼児 小学 6 年生 \\
\hline
\end{tabular}

*URLを表記したものは印刷物として入手するのは困難であるが, ホームページから入手できる（2007 年 3 月現在）.

う視点から解析し，テキスト間の比較を行った（テキスト 間の比較については III.2. で詳述)。さらに, 各テキストの 構造の差異に着目してテキストの分類を行った（III.3.で 詳述)。最後に，以上の結果を基に，IV. で多面的機能を題 材とする森林教育テキストの作成方針について考察した。

各プログラムで取り上げられている多面的機能を解析す るにあたっては, 以下に述べる明示的に記述された機能と， 潜在的に記述された機能に区別した。明示的に記述されて いるかどうかの判断基準としては，プログラム実施によっ て体験・理解される現象や森林の特徵が，プログラムの説 明文において森林の「機能（はたらき）」として紹介されて いるか否かによるものとした。機能が潜在的に記述されて いるかどうかの判断基準としては，プログラム実施によっ て理解される森林の特徵が穾質的に森林の機能 (はたらき) であり，説明を補えばある特定の森林機能を想起できるも のとした。たとえば，あるプログラムの説明文において， 「森林は木材生産機能を有する」もしくは「森林には木材を 供給する働きがある」といった表現があれば，このプログ ラムは明示的に物質生産機能を取り上げているとみなし， また「昔は裏山の薪を使って火を炊いていた」といった表 現を用いていれば潜在的に物質生産機能を取り上げている とみなした。一つのプログラムが複数の機能を取り上げて いる場合には，明示的，潜在的のそれぞれについて該当す る機能を列挙した。以上をもとに，テキストごとに森林の 各機能を取り上げたプログラム数を, 機能が明示的に取り 扱われているプログラムと, 潜在的に取り扱われているプ ログラムとに区別して集計した。どの機能も取り上げてい ないプログラムは「該当なし」として集計した。森林の多
面的機能は,「地球環境・人間生活にかかわる農業及び森林 の多面的な機能の評価について (答申)」（日本学術会議, 2001）の 8 分類（表-2）に従った。なお，答申においては 文化機能の中に「森林教育」が含まれているが, 森林教育 プログラムにあっては必然的に「森林教育」を包含するた め, 本研究では文化機能から「森林教育」を除外して解析 した。なお，プログラムにおける多面的機能の取り上げや， その集計結果として得られる各テキストの取り上げ数の違 いは，あくまで「多面的機能」という視点からの分類であ り，優劣を表すものではないことに注意を要する。

\section{III. 森林教育テキストの比較解析の結果と考察}

\section{1. 森林教育テキストの概要およびプログラムの絞り込み}

本研究では各テキストに扔ける教育プログラムを解析の 対象としたが，対象年齢や実施地域，プログラム以外の記 載事項などにはテキストによって違いがあった。それらの 違いに着目して, 各テキストの内容を以下に簡単に整理し, 必要に応じて解析対象とするプログラムの絞り込みを行っ た。なお，各テキストの番号は表-1に示したものである。

テキスト 1 は, 小学校の「総合的な学習の時間」での利 用を想定して作成されたプログラム集である。各プログラ ムは, プログラムの主題に応じたいくつかのアクティビ テイによって構成されており, 学習指導要領との対応が学 年別に示されている。内容的には，野外での観察・採集が 主となっている。また, 各プログラムの末には「資料」や 「森林づくりとの関わり」というプログラム実施上の技術的 なアドバイスが各 1 ページ設けられている。

テキスト 2 は，「総合的な学習の時間」などでの環境教育 
表-2. 森林の多面的機能

\begin{tabular}{|c|c|}
\hline 機能 & 概要 \\
\hline a 生物多様性保全機能 & $\begin{array}{l}\text { 遺伝子保全 } \\
\text { 生物種保全 } \\
\text { 植物種保全, 動物種保全 (鳥獣保護), } \\
\text { 菌類保全 } \\
\text { 生態系保全 } \\
\text { 河川生態系保全, 沿岸生態系保全 (魚 } \\
\text { つき) }\end{array}$ \\
\hline b 地球環境保全機能 & $\begin{array}{l}\text { 地球温暖化の緩和 } \\
\text { 二酸化炭素吸収, 化石燃料代替エネル } \\
\text { ギー } \\
\text { 地球気候システムの安定化 }\end{array}$ \\
\hline $\begin{array}{c}\mathrm{c} \text { 土砂災害防止機能 / } \\
\text { 土裹保全機能 }\end{array}$ & $\begin{array}{l}\text { 表面侵食防止 } \\
\text { 表層崩壊防止 } \\
\text { その他の土砂災害防止 } \\
\text { 落石防止, 土石流発生防止・停止促 } \\
\text { 進, 飛砂防止 } \\
\text { 土砂流出防止 } \\
\text { 土壤保全（森林の生産力維持） } \\
\text { その他の自然災害防止 } \\
\text { 雪崩防止, 防風, 防雪, 防潮など }\end{array}$ \\
\hline $\mathrm{d}$ 水源涵養機能 & $\begin{array}{l}\text { 洪水緩和 } \\
\text { 水資源貯留 } \\
\text { 水量調節 } \\
\text { 水質浄化 }\end{array}$ \\
\hline e 快適環境形成機能 & $\begin{array}{l}\text { 気温緩和 } \\
\text { 夏の気温低下 (と冬の気温上昇), } \\
\text { 木陰 } \\
\text { 大気浄化 } \\
\text { 塵芥吸着, 污染物質吸収 } \\
\text { 快適環境形成 } \\
\text { 騒音防止, アメニティー }\end{array}$ \\
\hline f 保健・レクリエーション機能 & $\begin{array}{l}\text { 療養 } \\
\text { リハビリテーション } \\
\text { 保養 } \\
\text { 休養 (安らぎ, リフレッシュ), 散策, } \\
\text { 森林浴 } \\
\text { レクリエーション（遊び） } \\
\text { 行楽, スポーッ, つり }\end{array}$ \\
\hline g 文化機能 & $\begin{array}{l}\text { 景観 }(\text { ランドスケープ)・風致 } \\
\text { 学習・教育 } \\
\text { 生产・労働体験の場, 自然認識・自然 } \\
\text { とのふれあいの場 } \\
\text { 芸術 } \\
\text { 宗教・祭礼 } \\
\text { 伝統文化 } \\
\text { 地域の多様性維持 (風土形成) }\end{array}$ \\
\hline h 物質生産機能 & $\begin{array}{l}\text { 木材 } \\
\text { 燃料材, 建築材, 木製品原料, パルプ } \\
\quad \text { 原料 } \\
\text { 食料 } \\
\text { 肥料 } \\
\text { 飼料 } \\
\text { 薬品その他の工業原料 } \\
\text { 抽出成分 } \\
\text { 緑化材料 } \\
\text { 観賞用植物 } \\
\text { 工芸材料 }\end{array}$ \\
\hline
\end{tabular}

「地球環境・人間生活にかかわる農業及び森林の多面的な機能の評価につ いて (答申)」（日本学術会議，2001）をもとに作成。

学習に用いることを想定した小学校中学年用の指導用手引 き書である。全 3 章からなり，各章はさらに細かく「森の 草や木」，「森にある土」などの節に分けられ，各節には 2〜 5 のプログラム例が示されている。また，各節ごとに，そ の節に含まれるプログラムの背景となる基礎知識に関する
解説や資料がまとめられている。本研究では, そのうち「森 といきもの」と「森とくらし」の章に含まれるプログラム を解析対象とした。

テキスト 3 は, テキスト 2 と同じく,「総合的な学習の時 間」などでの環境教育学習に用いることを想定した小学校 高学年用の指導用手引き書である。全 3 章からなり, 全体 の構成や題材もテキスト 2 と同様であるが，プログラムに おいて社会問題との関連を明確にするなど, 学習内容はよ り梁化したものとなっている。テキスト 2 と同様に「森と いきもの」と「森とくらし」の章に含まれるプログラムを 解析対象とした。

宮城県では, 上にあげたテキスト 2,3 の他に中学生向け のテキストも作成しているが, 中学生向けのテキストは学 習の題材についての参考情報を多く提示しているものの, 具体的なプログラムについては指針の記述にとどまってい るため, 本研究では解析対象から外している。

テキスト 4 は, 小中学校で森林を教材とする際に利用す ることを想定して作成されたプログラム集で, 各プログラ ムには対象学年や関連教科が提示されている。一つのプロ グラムあたりの説明が 2 ページと少ないが, プログラム数 は比較的多く, 内容も多岐にわたっている。また, プログ ラム集以外に，「森林のはたらき」や「神奈川県で見られる 樹木」などに関する解説, プログラムの作成の仕方, 神奈 川県内の森林関係の施設の案内などが記載されている。

テキスト 5 は, 天竜川流域の林業地帯における小中学校 での森林教育実施を想定して作成されたテキストで, プロ グラムの一部は実施対象地が限定されるものとなってい る。プログラムの内容は比較的高度で, 小学校高学年以上 向けであろう。各プログラムに対応して「学習の解説」が 付記されており，プログラムの背景が学べるよう配慮され ている。また，各プログラムは，「天竜美林の生い立ち」, 「森林の働き」など五つのグループに分けられ，プログラム を組み合わせて総合的な学習を行うための指針となってい る。テキストには, 「資料編」として, 学習に使用する器具 の入手先や参考図書, 関連施設, 各種統計情報など, 詳細 な資料がまとめられている。

テキスト 6 は，テキスト 5 と同様に, 駿東・田方という 特定の地域における小中学校での森林教育実施を想定して 作成されたテキストである。各プログラムには，プログラ ムの背景や関連する情報について 2 ～ 3 ページの解説が付 されている。また,テキスト 5 と同様にプログラムのグルー プ分けが行われている。本テキストでは，すべてのプログ ラムが森林を題材としているわけではないため, 本研究で は森林を題材としたプログラムのみを解析対象とした。

テキスト 7 は, 幼少期からの環境教育が重要であるとの 観点から作成されたプログラム集で，おもに幼児から小学 校低学年を対象とし, 各プログラムには対象（保育園・幼 稚園, 小学校低学年, 小学校中学年) が明示されている。 各プログラムは 2〜4のアクティビティから構成されるが, 対象年齢が低いことから，多くは観察・体験に終始してい 
る。また，テキストには「環境学習の進め方」に関する簡 単な手引きも収録されている。本研究では,「山・里編」の プログラムのうち，水田で実施されるプログラムを除いて 解析対象とした。

テキスト 8 は, 学校教育に限定せず, 施設管理者や森林 インストラクターなどの「指導者」が，森林教育を実施す る際の参考にすることを想定して作成されたアクティビ ティ集で，いくつかのアクティビティを組み合わせたプロ グラム事例が紹介されている。各アクティビティにはおよ その対象年齢が示されている。また，テキスト全体を通し て，地球温暖化と森林との関わりを学ぶという目標が設定 され，テキスト冒頭で温暖化の状況や影響，対策について の解説が記載されている。アクティビティの記述内では「地 球温暖化との関連」というコラムが設けられ，アクティビ ティと温暖化をどう結びつけるかについて簡単な説明があ る。

テキスト 9 は，おもに地方自治体で実施された森林環境 教育の事例について紹介したアクティビティ集である。テ キストの構成はテキスト 8 とほぼ同様である。紹介されて いるアクティビティの対象年齢は幅広いが，基本的には幼 児の参加を考慮した平易なアクティビティから構成され， 観察・体験が主体である。

テキスト 10 は, アメリカ森林研究所が作成した, 木を通 した環境教育プログラムの事例集であり，幼児から小学校 高学年までを対象とし，各プログラムに対象学年が示され ている。多くの事例が収録されているが，実施手順などの 記述がやや簡素であるため，経験者向けのテキストである との感が強い。また, 題材の特殊性や対象地が限定されて いるとの理由から日本では実施困難なプログラムもいくつ か含む。巻末には索引があり, 題材や学習法, 対象学年な どのキーワードによりプログラムをグループ化できるよう になっている。

以上，本研究で解析対象としたテキストについて，個々 のテキストの概要と解析対象の絞り込みについて述べた。 選定されたテキスト全体に共通するのは，いずれも現場で の適用を前提としていることであった。これらのテキスト
は，プログラム例を紹介して森林教育実施の参考にするこ とを意図して作成されているため，プログラム実施の手順 や必要な道具, 注意点などが具体的に記されていた。表-1 にみられるように，各テキストが想定するプログラムの実 施対象年齢は幼児から高齢者までと多様である。実施対象 年齢はテキストによって, 幼児〜小学校低学年，小学校中 学年, 小学校高学年, 大人, と扮抒よそ四つのカテゴリに 分けられ，テキスト 2 や 3 のうに，対象年齢が細かく設 定されている場合や，テキスト $4 ， 8 ， 9 ， 10$ のように，同 一テキスト内でもプログラムによって対象年齢が異なる場 合があった。実施地域については，テキスト 1 では掞もに 北海道でみられる植物種が紹介され，テキスト 5 と 6 には 実施対象地を限定したプログラムが含まれているが，多く のプログラムは対象地によらない, 汎用性のあるもので

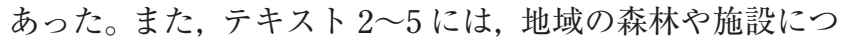
いての情報が参考資料としてまとめられており，テキスト 2，3，5，6，8には，プログラムの背景などについての解 説がプログラム本体の記述とは別に採録されているなど, 各テキストの内容と構成にはテキスト間で違いがみられ た。なお，テキスト 8 と 9 で取り扱われている各活動事例 は「アクティビティ」であるが，本研究では，これらを他 のテキストのプログラムと同等とみなして解析した。

\section{2. 森林教育テキストにおける多面的機能の取り上げら れ方}

表-1のテキストに含まれるプログラムについて, 各プロ グラムが森林の多面的機能をどのように取り上げているか を機能ごとに明示的か潜在的かを区別して集計し，その内 訳を表-3に示した。10 篇のテキストに含まれる全プログラ ム数は 279 であった。ただし, 内容の類似するプログラム が複数のテキストでみられるケースもいくつかあった。特 に，林業体験を題材としたプログラムで目立ち，間伐体験 のプログラムがテキスト $3 ， 4 ， 9$ に，下刈り体験のプログ ラムがテキスト $3 ， 4 ， 8$ にそれぞれ存在していた。他にも， 樹高測定を行うプログラムや落ち葉集めを題材としたプロ グラム, 森林土壤に関するプログラムなどで重複がみられ， それらの重複を考慮すると実質的なプログラム数は 250 程

表-3. 森林教育プログラムにおける森林の多面的機能の取り上げ数

\begin{tabular}{|c|c|c|c|c|c|c|c|c|c|c|c|c|c|c|c|c|c|c|c|c|c|}
\hline \multirow{3}{*}{$\begin{array}{c}\text { テキスト } \\
\text { 番号 }\end{array}$} & \multirow{3}{*}{$\begin{array}{l}\text { 対象とした } \\
\text { プログラム数 }\end{array}$} & \multirow{3}{*}{$\begin{array}{l}\text { 「該当なし」の } \\
\text { プログラム数 }\end{array}$} & \multicolumn{16}{|c|}{ 多面的機能の取り上げ数* } & \multirow[b]{3}{*}{ 明 } & \multirow{3}{*}{$\begin{array}{l}\text { 計 } \\
\text { 潜 }\end{array}$} & \multirow[b]{3}{*}{ 総 } \\
\hline & & & \multirow{2}{*}{\multicolumn{2}{|c|}{ a }} & \multicolumn{2}{|c|}{ b } & \multicolumn{2}{|c|}{$\mathrm{c}$} & \multicolumn{2}{|c|}{$\mathrm{d}$} & \multicolumn{2}{|c|}{$\mathrm{e}$} & \multicolumn{2}{|c|}{ f } & \multicolumn{2}{|c|}{$\mathrm{g}$} & \multicolumn{2}{|c|}{$\mathrm{h}$} & & & \\
\hline & & & & 潜 & 明 & 潜 & 明 & 潜 & 明 & 潜 & 明 & 潜 & 明 & 潜 & 明 & 潜 & 明 & 潜 & & & \\
\hline 1 & 22 & 1 & 5 & 13 & 2 & 0 & 1 & 0 & 1 & 0 & 2 & 0 & 3 & 4 & 3 & 3 & 3 & 2 & 20 & 22 & 42 \\
\hline 2 & 11 & 0 & 2 & 4 & 0 & 1 & 0 & 2 & 1 & 1 & 1 & 0 & 1 & 1 & 0 & 1 & 2 & 0 & 7 & 10 & 17 \\
\hline 3 & 13 & 0 & 4 & 1 & 3 & 0 & 1 & 1 & 2 & 1 & 2 & 0 & 1 & 0 & 0 & 0 & 2 & 3 & 15 & 6 & 21 \\
\hline 4 & 43 & 2 & 4 & 11 & 0 & 0 & 1 & 1 & 1 & 1 & 0 & 0 & 2 & 7 & 4 & 8 & 15 & 5 & 27 & 33 & 60 \\
\hline 5 & 25 & 0 & 6 & 2 & 3 & 1 & 4 & 1 & 4 & 1 & 3 & 1 & 4 & 1 & 12 & 1 & 11 & 3 & 47 & 11 & 58 \\
\hline 6 & 12 & 1 & 3 & 4 & 1 & 0 & 0 & 1 & 0 & 2 & 0 & 0 & 0 & 0 & 4 & 0 & 5 & 1 & 13 & 8 & 21 \\
\hline 7 & 17 & 0 & 2 & 8 & 0 & 0 & 0 & 0 & 0 & 1 & 0 & 0 & 6 & 6 & 0 & 6 & 0 & 3 & 8 & 24 & 32 \\
\hline 8 & 30 & 3 & 0 & 9 & 1 & 1 & 0 & 0 & 0 & 0 & 0 & 0 & 7 & 8 & 3 & 7 & 8 & 7 & 19 & 32 & 51 \\
\hline 9 & 28 & 1 & 0 & 11 & 1 & 0 & 0 & 0 & 0 & 1 & 0 & 0 & 5 & 7 & 1 & 2 & 9 & 6 & 16 & 27 & 43 \\
\hline 10 & 78 & 19 & 6 & 19 & 0 & 1 & 2 & 0 & 1 & 1 & 2 & 2 & 4 & 10 & 9 & 4 & 9 & 11 & 33 & 48 & 81 \\
\hline 計 & 279 & 27 & 32 & 82 & 11 & 4 & 9 & 6 & 10 & 9 & 10 & 3 & 33 & 44 & 36 & 32 & 64 & 41 & 205 & 221 & 426 \\
\hline
\end{tabular}

* a, 生物多様性保全機能; $\mathrm{b}$, 地球環境保全機能 ; $\mathrm{c}$, 土砂災害防止機能/土壤保全機能 ; d, 水源涵養機能 ; e, 快適環境形成機能; $\mathrm{f}$, 保健・レクリエー ション機能; $\mathrm{g}$, 文化機能; h, 物質生産機能。プログラムでの各機能の取り上げが明示的 (明) か, 明示的でないか (潜) で区別している。 
度であった。なお，本研究では，こうした重複プログラム もそれぞれ一つと数え，279 プログラムについて解析を 行った。

多面的機能の取り上げ状況については, すべての機能が いずれかのプログラムで取り上げられている一方で, 機能 によって取り上げているプログラム数に偏りがあった(表3)。すなわち, 明示的・潜在的を合わせると, 生物多様性 保全機能を取り上げたプログラムが最も多かった。これは 森林における生物観察を主とするプログラムが多かったた めである。次いで，林業体験や木材加工を題材としたプロ グラムが多かったため, 物質生産機能の取り上げ数が多 かった。保健・レクリエーション機能の取り上げ数も多 かったが，ゲームなど森林を実施の場としてのみ用いるプ ログラムも含まれていた。また，文化機能を取り上げたプ ログラムには，森林にある素材を用いた図工・美術の作品 づくりを通して感性を養うなどの例を多く含んでいた。一 方，取り上げたプログラム数が少なかったのが地球環境保 全機能, 土砂災害防止機能/土壤保全機能, 水源涵養機能, 快適環境形成機能の四つの機能であった。なお，森林の多 面的機能のどの機能も取り上げておらず「該当なし」となっ たプログラムの大部分は，樹木や植物の形態・構造など森 林・樹木に関する，いわば基礎知識を題材とするプログラ ムであった。「該当なし」となったプログラム数はテキスト 10 を除いて多くはなく, テキスト 10 は木を通した環境教 育プログラム集であったために，このような基礎知識的な 事項についてのプログラムが多かった。

各プログラムに拈ける多面的機能の取り上げ方が明示的 かどうかに着目すると，すべての機能について明示的に取 り上げたプログラムが少なからず存在していた（表-3）。す なわち，表-1に示した森林教育テキストには，森林の機能 との対応が図られたプログラムが数多く収められていた。 機能を明示的に取り上げたプログラムののべ総数は 205 ,

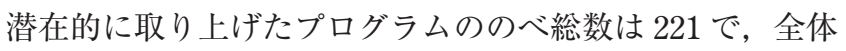
ではほぼ同数であった。ただし，テキストによって差がみ られ，テキスト $3 ， 5 ， 6$ では，いずれも明示的なものの割 合が潜在的なものに比較してかなり大きかった。

また, 一つのプログラムが複数の機能を取り上げた場合 があった。表-3に扔いて, 対象としたプログラム数から 「該当なし」のプログラム数を除外したものと, 機能の取り 上げ数合計を比較すると，すべてのテキストで機能の取り 上げ数は対象プログラム数より大きくなる。テキスト 1 と 5 では機能の取り上げ数がプログラム数の 2 倍を超えてい た。多くの場合, 一つのプログラムで取り上げる機能の数 は $2 \sim 3$ であったが, テキスト $1 に は$, 森林の多面的機能そ のものを主題としてすべての機能を明示的に取り上げたプ ログラムもあった。

テキストごとの多面的機能の取り上げ数をみると（表3)，すべての機能を明示的に取り上げていたのはテキスト 1 と 5 のみであったが, 他の多くのテキストでも複数の機 能を明示的に取り上げていた。また，全体として取り上げ
られたプログラム数が少なかった地球環境保全機能, 土砂 災害防止機能/土畩保全機能, 水源涵養機能, 快適環境形成 機能の四つの機能についても, それぞれ半数程度のテキス トが明示的に取り上げていた。一方で，テキスト 7 は明示 的には二つの機能しか取り上げて抢らず，全テキストの中 でもっとも少なかった。これは，テキスト 7 の対象年齢が 低く, 実施可能なプログラムの種類が限られたことが大き な理由だと思われる。対象年齢の低いプログラムの多くは, 「遊び」や「体験」の要素を取り入れた上で, 生物多様性保 全機能や保健・レクリエーション機能, 文化機能を, それ ぞれ生物観察やゲーム, 作品づくりなどの形で潜在的に取 り上げる傾向があり, 同じ機能を取り上げている場合でも, 対象年齢によってプログラム内容に大きな違いがあった。 これらのことから, 多面的機能を題材とした森林教育は, ある程度の年齢以上を対象とすることが現実的であること が示唆される。具体的には, 今回解析したテキストからは 小学校中学年以上を対象とすることが現実的であると考え られる。

以上をまとめると, 森林の多面的機能そのものを主題と したテキストは, 単体では作成されていないものの, 既存 の森林教育テキストの中には, 森林の機能を明示的に題材 としたプログラムが複数存在しており，いくつかのテキス トを通して適宜プログラムを集めれば，すべての機能を網 羅することが可能であった。解説を補うことで森林の多面 的機能を題材としたプログラムとなりうるものも多数あっ たことと合わせて，すでに存在しているプログラムを参照 することで, 森林の多面的機能を主題とした森林教育を実 施することは可能といえる。また, 森林の多面的機能を題 材とした森林教育を行う場合, 一つのプログラムで複数の 機能を題材とすることが可能である。ただし, 幼児や小学 校低学年を対象とした教育プログラムについては, 森林の 多面的機能を明示的に題材としているものは少ない。

\section{3. 森林教育テキストの構造に着目した分類}

III.1.でみたように，それぞれのテキストに打ける各プ ログラムの記述内で，プログラム実施のために必要となる 具体的な情報は基本的にすべて網羅されていたが, プログ ラム以外の参考資料や解説などの有無に違いがあった。特 に, プログラムの背景となる知識や主題についての解説の 有無や配置はテキスト構成上の大きな違いとなっていた。 たとえば，テキスト 6 では各プログラムの説明とともに数 ページにわたって関連知識の解説がなされており, テキス ト 2 ではいくつかのプログラムごとに共通の解説を参照す る構成となっていた。一方, テキスト 9 や 10 にはそのよう な解説がなかった。そこで, そのような解説によって示さ れるプログラムの背景や主題を, 広嶋ら（2006）にならっ て「テーマ」として, 表-19テキストをプログラムとテー マの関係性によって分類することを試みた。

図-1 はプログラムとテーマの関係性に着目してテキス 卜の構造を類型化した際の概念図である。図-1において, a はテキストがテーマをもたず単にプログラムの集合から 


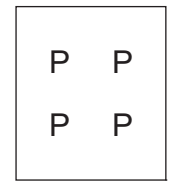

a

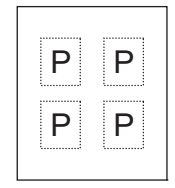

b

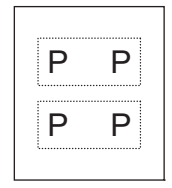

C

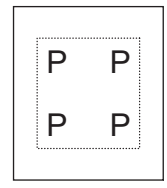

d
図 -1 . 森林教育テキストの構造の分類

実線はテキスト，点線はテーマ，Pはプログラムを示す。

なる場合で，テキスト $1,4,7,9,10$ が該当した。bはテ キスト内の各プログラムに対応するテーマが個別に存在し ており，テキスト $5 ， 6$ が該当した。cはテキスト内のプロ グラムが対応するテーマによっていくつかのグループに分 けられて抢り，テキスト $2 ， 3$ が該当した。d はテキスト全 体が一つのテーマの下で編集されており，すべてのプログ ラムがこのテーマに対応する。プログラム全体を通して「地 球温暖化と森林」というテーマが設定されていたテキスト 8 がこれに該当した。な扔，テーマに関する記述の分量は， テキスト $2,3,5$ では 1 ページ, テキスト 6 では 3 ページ, テキスト 8 では 4 ページであった。

以上から，既存の森林教育テキストは構造上，まずテー マの有無により大きく分類できた。本研究で対象としたテ キストでは，テーマをもつものともたないものが半数ずつ 存在した。さらに, テーマをもつ場合でも，図 -1 の b d のように，プログラムとテーマとの対応は一様ではなかっ た。このようなテキストの構造は，テキスト作成の目的や 方針によって異なると思われるが，今後，多面的機能を題 材とした森林教育テキストを作成する際にどのような構造 が適しているかについて，次節で考察する。

\section{IV. 多面的機能を題材とした森林教育テキストの 作成方針についての考察}

III.2.でみたとおり，森林の機能を取り上げた教育プロ グラムはすでに数多く存在しており, 今後, 多面的機能を 題材とした森林教育を実施していく上でそれらを参照する ことが可能である。しかしながら，すべてのプログラムが どの地域でもそのまま適用できるとは限らない。事実，テ キスト 5 や 6 のように特定の地域での実施を想定したテキ ストも存在しており，既存のプログラムを各地域に対して どう適用するかの情報が欲しいという教育現場からの要求 （青田ら，2003; 石橋 -内出，1995; 黒羽ら，2003; 関岡, 1999 ; 島田，2003）も数多い。すなわち, 既存のプログラ ムを実施する場合にも，実際の実施場所や条件に応じた実 施要領が必要であり，それらの情報が既存のプログラムに 加えて記載されたテキストが必要である。したがって，今 後も森林教育実施に際して専門家によるテキストの作成が 求められる場面は多いと考えられる。

一方, 森林の多面的機能を題材とした森林教育を行うと いうことは，1）森林の特性を「はたらき」（機能）として 実感・理解し，2）それらの「はたらき」がいくつも（多面
的に）存在することを理解する，と換言できるだろう。森 林教育の対象者に占める览童の割合が高いことを考える と, 単に森林内でプログラムを体験しただけではこれらを 理解することは困難だといえる。一般に, 環境教育を実施 する際にはインタープリテーション（解説）が重要である (Regnier et al., 1994)。森林の多面的機能を題材とした森林 教育を行っていく上でも，たとえばテキスト 8 にみられる ように, プログラム実施時に森林の機能と関連づけられた インタープリテーションを行えるよう配慮することが重要 であろう。したがって, 森林の多面的機能を題材としたテ キストを作成していく上で，適切な教育プログラムを開 発/選定して実施要領を記述することに加え, 教育プログ ラムのインタープリテーションを通して森林の多面的機能 についての理解が深まるように，学校教員自身がプログラ 厶と多面的機能の対応関係や多面的機能そのものについて 理解できるような解説を記述することが重要である。すな わち，テキストは単にプログラムを提供するのみならず， プログラムの実施者である学校教員に対して, プログラム の具体的な実施手順とともにプログラムの背景にある森林 の多面的機能に関する知識を提供するとともにその理解を 促し，インタープリテーションを適切に実施することを促 す役割をもつべきであろう。

既存の森林教育テキストは，III.3. で整理したとおり， テーマとプログラムの関倸に着目した構造で類型化でき た。ここで，上述のインタープリテーションのための解説 は，テーマに関連した記述に相当する。テキストがテーマ を含む場合にも，いくつかの構造が存在した（図 -1 b, c, d)。「森林の多面的な機能の最大の特徴は極めて多様な機 能をもつこと」であり，「多くの機能を重複して発揮でき， 総合的に強力なことが森林の機能」の本質的な特徵であり ながら,「実際に森林の機能が論議されるときには単独の機 能についてのみ論議されることが多く, 注意を要する」こ と（日本学術会議, 2001）を考えると, 学校教員用のテキ ストには森林の各機能や機能間の関係（トレード・オフな ぞ）についての複数のテーマ設定と, それに対応した解説 が必要であろう。したがって, 森林の多面的機能を題材と したテキストの構造としては, 図-1のb $\mathrm{b}$ cがふさわしい ことになる。特定の場所や児童を対象とし, 多種多様なプ ログラムを必要としない状沉での森林教育を想定したテキ ストには構造 b が適しており, 対象児童の学年に幅がある 場合や，さまざまな形態（野外体験・実験・実演など）で のプログラム実施が想定されるなど，プログラムにいくつ かの選択肢が求められる場合には構造 c が適しているであ ろう。

構造 $\mathrm{b}$ と $\mathrm{c}$ に該当するのは, それぞれテキスト 5,6 とテ キスト $2 ， 3$ であった。III.2.で述べたように，テキスト 3 , 5,6 で, 明示的に機能を取り上げたプログラム数が明示的 でないプログラム数を大きく上回っていた（表-3）。テキス 卜 2 の対象が小学生低学年であり, 高度な学習が困難であ ろうことを考慮すると, 多面的機能を題材としたテキスト 
を作成する際にふさわしい構造だと考えられた構造 b や $\mathrm{c}$ のテキストにおいて, 実際に明示的に機能を取り上げたプ ログラムが多いといえそうである。すなわち, テーマの存 在が, プログラム内での森林機能の明示的な取り上げを容 易にしている可能性が考えられる。このことからも, 森林 の多面的機能を題材とした森林教育テキストを作成する場 合には，構造 b p c のように，テーマを設定したテキスト を作成することが重要だと考えられる。

最後に補足として，テキストに扔けるテーマは必ずしも 多面的機能に関する事柄に限定されず，テキスト 5 や 6 の ように, 教育現場での必要に応じて地域の特性や森林以外 の題材を扱うことも環境教育の観点から重要である。また, 各テーマに関する記述はプログラムのインタープリテー ションを提供するための実用的な参考資料となるため，本 研究で取り上げたテキスト $(2 ， 3 ， 5 ， 6 ， 8 ）$ と同様，あま り分量を多くしないことが適当であろう。今回対象とした プログラムの多くが複数の機能を取り上げていたことか ら，あるプログラムが複数のテーマから参照されるような 構造も考えられる。テキスト 10 のように索引を設けたり， テーマやプログラム内で他のテーマやプログラムとの関連 性を明記するなどして，プログラム間の結びつきを多様な 視点から理解できるように工夫することも，森林の機能を 多面的に理解するため, 背景知識を墚めるために有効であ ろう。

\section{V. おわりに}

森林の多面的機能を題材とした森林教育を広く実施して いくにあたって，学校教員を対象としたテキストを活用す ることが有効であるとの立場から，既存の森林教育テキス トの内容をレビューし, 多面的機能の取り上げ方の解析と, テキストの構造に着目した整理を行い，以下のような結論 を得た。

既存の森林教育テキストの中には, 森林の機能を題材と したプログラムが多く存在していること，それらのプログ ラムによって「地球環境・人間生活にかかわる農業及び森 林の多面的な機能の評価について(答申)」（日本学術会議, 2001）において八つに分類された森林の多面的機能が網羅 されていることが示された。また，既存の森林教育テキス トは，プログラムとそれに対応するテーマ（主題・背景） によって,いくつかの構造に類型化できることが示された。 その上で, 今後, 森林の多面的機能を題材とした森林教育 テキストを作成する際には，プログラムとそれに対応した 森林の多面的機能に関するテーマの組み合わせを複数盛り 込むことが，森林の多面的機能に関する理解の向上を図る 上で有効であると考えられた。

本研究は東京大学大学院農学生命科学研究科の専攻間共 同研究費（2003～2004 年度）により実施されたものであ る。関係各位のご理解とご協力に感謝したい。

\section{引用文献}

アメリカ森林協議会（ERIC 国際理解教育センター編訳）（1999）木と 学ぼう プロジェクト ラーニングッリー活動事例集（幼〜小

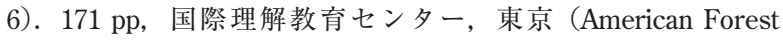
Council (1975) PROJECT LEARNING TREE Activity Guide K-6).

青田 勝 - 吉田茂二郎 - 池田朝二 ・ 伊東啓太郎 - 村上拓彦 - 今田盛 生 (2003) 小学校における森林環境教育と自然観について一直方 市と日田市の場合一. 日林学術講 $114: 228$.

芦原誠一・松元正美・野下治己・内原浩之・松野嘉昭・井之上俊 治・井倉洋二 (2003) 大学演習林がつくる子ども向け野外教育プ ログラム—小学校の森林教室を例に一. 日林学術講 $114: 216$.

広嶋卓也 - 山本清龍 - 田中延亮 - 柴崎茂光 - 堀田紀文 - 坂上大翼 （2006）富士山を題材とした森林教育プログラムの開発, 実践と 効果把握一初等・中等学校における森林教育実践上の課題と対 応策一. 日林誌 $88: 160-168$.

比屋根哲 (2001) 森林教育の理念と研究の課題一議論の素材として. 森林科学 $31: 30-37$.

比屋根哲 - 山本信次 - 大石康彦 (2002) 森林教育の課題と展望. 東北 森林科学会誌 7(1) : 48-51.

北海道林業改良普及協会 (2000) 森で学ぶ 森林教育プログラム作成

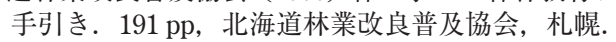

井倉洋二 (2003) 大学の森の森林教育. 森林科学 37：33-38.

井倉洋二・芦原誠一・松元正美 - 野下治己 - 内原浩之・松野嘉昭 （2004）体験から学ぶ森と川のプログラム—演習林における小学 校の総合学習受け入れ授業一. 日林学術講 $115: 388$.

石橋整司・内出美智子 (1995) 使いやすくわかりやすい教材とは一小 学校社会科教育における森林教育のための副教材一. 林業技術 639 : 28-31.

上沼昭彦 (2003) 学友林整備事業. 森林科学 $37: 28-32$.

（社）かながわ森林づくり公社（2004）森へ行こう 親しむ・知る・育 てる かながわの森〜小中学生にさせたい森林活動プログラム 集〜. 119 pp, http://www.ny.airnet.ne.jp/k_sinrin/pg/35.html.

黒羽修子・白鳥苗子・関岡東生 (2003) 森林教育活動における教材開 発に関する研究 I一市民による森林づくり活動における紙媒体 テキストの活用状況とその内容について一. 日林学術講 114 : 222.

松尾佳秀 - 大崎智弘 - 安川直樹 - 阿部光敏 - 酒井徹朗 - 守屋和幸 （2004）小学校における情報機器を活用した地域の自然体験学習 の取り組み. 日林学術講 $115: 390$.

宮城県環境生活部・(財) みやぎ・環境とくらし・ネットワーク （2004）みやぎ環境学習プログラム 小学校中学年. $47 \mathrm{pp}$, http:// www.pref.miyagi.jp/kankyo-s/kankyokyoiku/education_program. htm.

宮城県環境生活部・(財) みやぎ・環境とくらし・ネットワーク (2004) みやぎ環境学習プログラム 小学校高学年. $47 \mathrm{pp}, \mathrm{http}: / /$ www.pref.miyagi.jp/kankyo-s/kankyokyoiku/education_program. htm.

関岡東生（1999）わが国における野外教育の展開と森林教育. 林業経 済 $52(2): 1-7$.

楢崎達也 - 岩本佳久 - 中尾 諭 - 中山康成 - 山本隆教 - 倉野英明 岡田一郎・佐瀬知史・木原浩貴・山田 昭 (2004) 多様な主体の 協働による環境教育プログラム実践の事例. 日林学術講 115 : 389.

日本学術会議 (2001) 地球環境・人間生活にかかわる農業及び森林の 多面的な機能の評価について (答申). $107 \mathrm{pp}$, 日本学術会議, 東京.

荻原 彰（2002）アメリカにおける環境教育の取り組み。(環境教育 への招待. 川嶋宗継・市川智史・今村光章編著, ミネルヴァ書 房, 京都). 271-278.

大石康彦 (2001) 森林体験の実践と可能性. 森林科学 31:2-8.

大石康彦・佐藤謙司・佐々木修子・菊地幸子・岩根好伸 (2003) 森林 体験学習による小学生の森林意識の変容. 日林学術講 $114: 229$.

奥山洋一郎・茂田和彦 (2003) 学校林の歴史と現況. 森林科学 37： $4-9$.

奥山洋一郎・竹本太郎・永田 信 (2003) 事例に見る新しい学校林の 利用と管理. 日林学術講 $114: 211$. 
Regnier, K., Gross, M., and Zimmerman, R.（倉野雅子・ホーニング睦 美訳）（1994）インタープリテーション入門. 207 pp，小学館, 東京 (Regnier, K., Gross, M., and Zimmerman, R. (1992) The Interpreter's Guidbook; Techniques for Programs and Presentations. UW-ST Foundation Press, Inc., Seavens Point)

佐藤孝弘・青柳かつら（2003）北海道における森林教育研究への取り 組み一森林教育研究のためのプログラム作成の経過と今後の課 題一. 日林学術講 $114: 226$.

島田欣也 (2003) 学校林活動の活性化を目指して. 森林科学 $37: 23$ 27.

静岡県中遠・北遠・西部農林事務所 (2004) 天竜美林の教え〜天竜流 域で行う森林を中心とした環境学習の手引き〜. $115 \mathrm{pp}, \mathrm{http} / / /$ www.pref.shizuoka.jp/kankyou/ka-030/kyoikudownload.html 静岡県環境森林部・静岡県東部農林事務所 (2004) 駿東・田方地区で 考える森林環境教育プログラム集. 79 pp, http://www.pref. shizuoka.jp/kankyou/ka-030/kyoikudownload.html

山口県環境政策課 (2003) こども環境学習プログラム 山・里編. 184. http://eco.pref.yamaguchi.jp/study/network/kkgp.htm.

全国森林組合連合会（1999）ふれあい・まなび・つくる〜森林環境

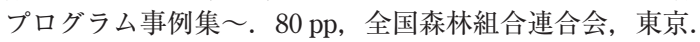

全国森林組合連合会（2002）したしみ・きづき・まなぶ．森林環境教 育プログラム事例集(2)一地方自治体編一. $80 \mathrm{pp}$, 全国森林組合 連合会，東京. 